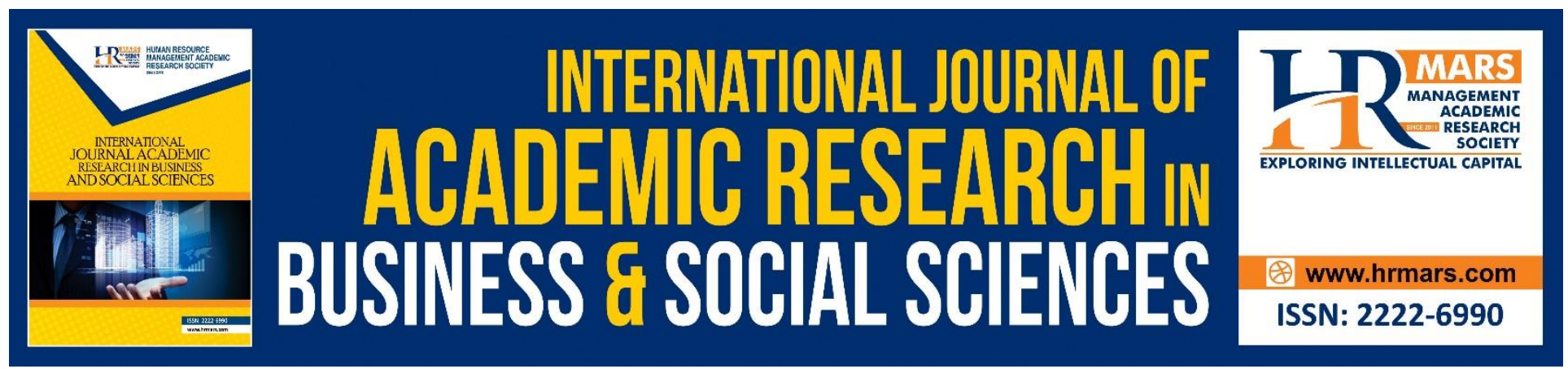

\title{
Investigating Second Language Anxiety among Polytechnic Students
}

\section{Maizan binti Mohamad}

To Link this Article: http://dx.doi.org/10.6007/IJARBSS/v10-i7/7479

DOI:10.6007/IJARBSS/v10-i7/7479

Received: 17 April 2020, Revised: 24 May 2020, Accepted: 21 June 2020

Published Online: 27 July 2020

In-Text Citation: (Mohamad, 2020)

To Cite this Article: Mohamad, M. B. (2020). Investigating Second Language Anxiety among Polytechnic Students. International Journal of Academic Research in Business and Social Sciences. 10(7), 632-637.

\section{Copyright: (C) 2020 The Author(s)}

Published by Human Resource Management Academic Research Society (www.hrmars.com)

This article is published under the Creative Commons Attribution (CC BY 4.0) license. Anyone may reproduce, distribute, translate and create derivative works of this article (for both commercial and non-commercial purposes), subject to full attribution to the original publication and authors. The full terms of this license may be seen at: http://creativecommons.org/licences/by/4.0/legalcode

Vol. 10, No. 7, 2020, Pg. 632 - 637

Full Terms \& Conditions of access and use can be found at http://hrmars.com/index.php/pages/detail/publication-ethics 


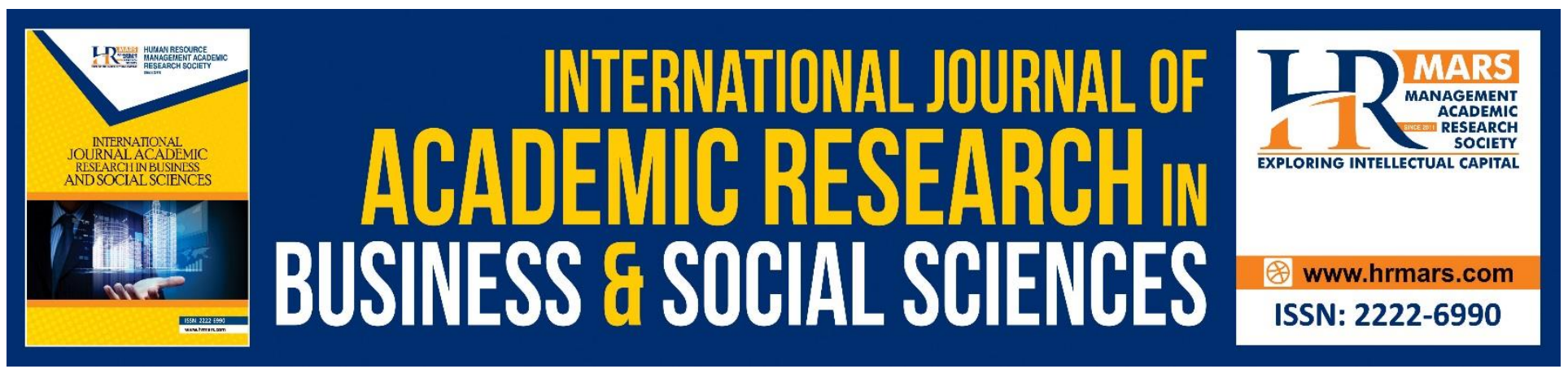

\title{
Investigating Second Language Anxiety among Polytechnic Students
}

\author{
Maizan binti Mohamad \\ Politeknik Hulu Terengganu \\ Email: jangmaizan@gmail.com
}

\begin{abstract}
Second language learning is a difficult task for many language learners and teaching the language is a challenging job to educators. One of the main contributors to this issue is anxiety. In relation to this, the present study aims are to find out the anxiety level of the students and to investigate the types of anxiety experienced by the students. The Foreign Language Classroom Anxiety Scale (FLCAS) which is developed by Horwitz was administered to 123 diploma students. Data analysis on the FLCAS items were analysed using SPSS 22. The findings revealed that majority of the students experienced a moderate level of English language anxiety with fear of negative evaluation ranks the first, followed by communication apprehension and test anxiety. The findings from this study provide pedagogical implications to the English as Second Language (ESL) practitioners and could potentially assist educators in improving their teaching and learning process in order to improve students' performance.
\end{abstract}

Keywords: English Language, Anxiety, Types, Level.

\section{Introduction}

English language plays an important role in Malaysian education system. The minimum period of formal English language learning in Malaysian education system is eleven years, which refers to six years in primary school and five years in secondary school. English language is a compulsory subject at all levels of education from primary to tertiary including at Polytechnics Malaysia. English is a compulsory subject to pass in order to graduate from this institution.

Polytechnic is one of the tertiary education providers. Malaysian polytechnic is one of the hubs for Technical and Vocational Education and Training (TVET) higher learning institutions in Malaysia. Polytechnic always makes improvements especially in the quality of teaching and learning. Even though polytechnics education focuses on technical programmes and practice-based learning, English is not neglected as it is an added value to their graduates.

However, many language learners face a big problem with their intrapersonal difficulties in using the targeted language. One of the difficulties is anxiety. Anxiety might hinder students from using the language as they will avoid speaking in English. Spielberg defines anxiety as "the subjective feeling of 
INTERNATIONAL JOURNAL OF ACADEMIC RESEARCH IN BUSINESS AND SOCIAL SCIENCES

Vol. 10, No. 7, July, 2020, E-ISSN: 2222-6990 @ 2020 HRMARS

tension, apprehension, nervousness, and worry associated with an arousal of the nervous system" (Spielberg, 1983, p.4)

Polytechnics always maintain the main purpose of teaching and learning English is to make sure the students are able to communicate in English. If the anxiety problem is not taken care of among the students, learning objectives might not be achieved.

"The use of the target language is one of the main purposes in learning second languages for many L2 learners, and it has been widely assumed that the use of the target language is also an indicator of and a necessary condition for successful second language acquisition (SLA)" (Hashimoto, 2002, p.29).

Students must be able to use the language in order to transfer information by sharing their knowledge and thoughts. Anyhow anxiety that exists impedes students from speaking in English language.

Thus the objectives of this paper are to find out the anxiety level of the students and to investigate the types of anxiety experienced by the students.

\section{Methodology}

\section{Participants}

The study was conducted on diploma students from two programmes which are from Commerce and Tourism Management Departments at one polytechnic in the East Coast of Peninsula Malaysia. There were a total of 123 students involved in this study.

Research Instrument and Data Analysis

For the purpose of this study, a set of questionnaire was adapted from the Foreign Language Classroom Anxiety Scale (FLCAS) which was developed by Horwitz (1986). The three types presented in the FLCAS, namely, reflective of communicative apprehension, test anxiety and fear of negative evaluation, are suitable and appropriate in the context of this paper.

The FLCAS scale includes 33 items, of which eleven items are related to communication anxiety, seven items for fear of negative evaluation and fifteen items to test anxiety. The respondents were asked to rate each item on a five-point Likert scale ranging from 1 ("strongly disagree") to 5 ("strongly agree"). The data obtained from the questionnaire is presented in the form of descriptive statistics which was analysed through SPSS (Statistical Package for Social Science) version 22.

\section{Results and Discussion}

The anxiety level of the students

The first research problem deals with anxiety level of the students. The data were analyzed by summing respondents' total score and calculating the mean score. The result is presented on the following table: 
INTERNATIONAL JOURNAL OF ACADEMIC RESEARCH IN BUSINESS AND SOCIAL SCIENCES Vol. 10, No. 7, July, 2020, E-ISSN: 2222-6990 @ 2020 HRMARS

\section{Table 1}

Minimum and maximum score respondents' foreign language anxiety

\begin{tabular}{l|l|l|l|l}
\hline & $\mathrm{N}$ & Minimum & Maximum & Mean \\
\hline Totalscoreflcas & 123 & 52.00 & 153.00 & 97.88 \\
\hline
\end{tabular}

Table 1 displays the students' anxiety level. $\mathrm{N}$ is the total respondents who completed the questionnaires. It consists of 123 students. By referring to (Foreign, 1986) the scoring were classified into these three categories:

\section{Table 2}

Categories of FLCAS Scoring

\begin{tabular}{lll}
\hline Category & Range & Level \\
\hline $\mathbf{1}$ & Score from 33 to 75 & low level of anxiety \\
$\mathbf{2}$ & From 76 to 119 & medium \\
$\mathbf{3}$ & Above 120 & high intensity anxiety
\end{tabular}

Based on the result, the minimum score of anxiety reported by the individuals was 52 , which is low anxiety level while the maximum score was 153 , which is high intensity anxiety. The mean score of 97.88 indicated that moderately high anxiety level.

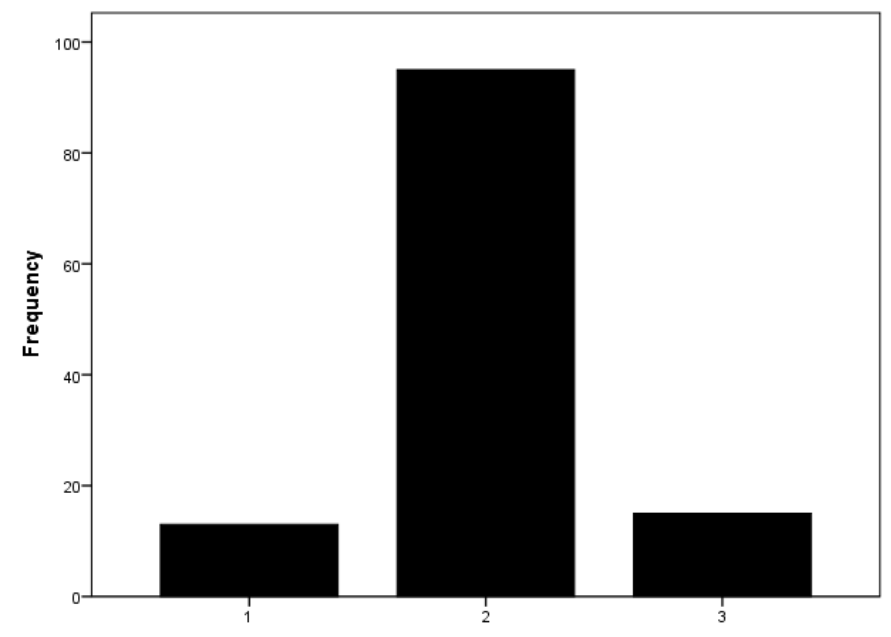

Figure 1 Level of English language anxiety

It can be seen in the figure 1, majority of the students were in medium level of English language classroom anxiety. 
INTERNATIONAL JOURNAL OF ACADEMIC RESEARCH IN BUSINESS AND SOCIAL SCIENCES Vol. 10, No. 7, July, 2020, E-ISSN: 2222-6990 @ 2020 HRMARS

\section{Table 3}

Level of Anxiety in Three Categories

\begin{tabular}{llllll} 
& & Frequency & Percent & $\begin{array}{l}\text { Valid } \\
\text { Percent }\end{array}$ & $\begin{array}{l}\text { Cumulative } \\
\text { Percent }\end{array}$ \\
\hline Valid & 1 & 13 & 10.6 & 10.6 & 10.6 \\
& 2 & 95 & 77.2 & 77.2 & 87.8 \\
& 3 & 15 & 12.2 & 12.2 & 100.0 \\
& Total & 123 & 100.0 & 100.0 & \\
\hline
\end{tabular}

As shown in the table 4.5 , majority of the respondents $(77.2 \%)$ indicated they experienced a medium level of anxiety in their current position as English language learners. 12.2\% of the respondents showed that they identify themselves as having high level of anxiety whereas only $10.6 \%$ of respondents are found to be showing low level of classroom anxiety as English learners. This indicated that the majority of the respondents, who were teenagers, do perceive themselves as having a moderate level of anxiety as reported by similar studies which investigated the level of anxiety among adolescent English language learners in Malaysia (Alias \& Rashid, 2018; Miskam \& Saidalvi, 2018; Baharudin \& Md. Rashid, 2014).

Anxiety can be viewed in a positive and beneficial light Spade, and Lightbown (2006) explained in their book that not all anxiety is bad and at a certain amount of tension can give positive effects. Besides that it can facilitate learning a second language. Moderate level of anxiety can increase students' motivation to learn especially to make preparation for English classes as well as to be evaluated in tests and assessments. Logically without anxiety, students might take easy in learning a second language. With the moderate anxiety level students will be more aware of their speaking skills so that they might speak with minimal mistakes. However, excessive amount of anxiety as an affective factor might discourage students from expressing and giving their ideas and opinions in English thus preventing them from willingly to communicate in English as a second language.

\section{The Types of Anxiety Experienced by the Students}

Table 4 presents findings based on the type of anxiety the students experienced. According to the table 1 fear of negative evaluation ranks the first $(M=3.12, S D=1.16)$, followed by communication apprehension ( $M=3.02, S D=1.14)$ and test anxiety $(M=2.90, S D=1.12)$. Therefore, fear of negative evaluation is the main contribution factor to the foreign language classroom anxiety. However, if it is reviewed from the mean scores, there is only slight difference between these three types of anxiety. This shows that the students face all the three anxiety components.

Majority of the students have to face fear of negative evaluation. This means that students get problems in coping with evaluation from friends and English lecturer in class (Mahfuzah, Rafidah, \& Akma, 2015). Polytechnic students are afraid of being evaluated since the assessments are more on speaking skills like presentation, role play, group discussions and mock interview. In other words students need to be aware of their speaking skills and grammatical error in order to use the language in class since they will be assessed by their friends and language lecturer. 
INTERNATIONAL JOURNAL OF ACADEMIC RESEARCH IN BUSINESS AND SOCIAL SCIENCES Vol. 10, No. 7, July, 2020, E-ISSN: 2222-6990 @ 2020 HRMARS

\section{Table 4}

Types of Anxiety

\begin{tabular}{llll}
\hline Components & Mean score & $\begin{array}{l}\text { Std. } \\
\text { Deviation }\end{array}$ & Rank \\
\hline Fear of negative evaluation & 3.12 & 1.16 & 1 \\
Communication apprehension & 3.02 & 1.14 & 2 \\
Test anxiety & 2.90 & 1.12 & 3 \\
\hline
\end{tabular}

\section{Conclusion}

Based on the findings, it can be concluded that students have all of the anxiety types. They are found to be very anxious about the evaluation of others negatively. Another finding is that the level of anxiety among students is generally at a moderate level. Therefore, to alleviate such anxiety among students, language lecturer must be more creative to tackle this issue. They can try autonomous and interesting learning methods of teaching in their classes to motivate their students as well as to minimize the feeling of anxiety in the process of second language acquisition. Besides that, it is suggested for future research to conduct researches on the relationship between anxiety and willingness to communicate since the main issue in polytechnic Malaysia now is how to encourage the students to communicate in English. Thus this will help English lecturers to help the students who are reluctant to communicate in English to improve their speaking skills.

\section{Acknowledgments}

Thank you very much to Politeknik Malaysia for giving me a big chance to further my study by giving me scholarship, to my great supervisor, Dr. Zailani binti Jusoh, UniSZA for her great support and knowledge shared. To my life partner, my lovely mother, my kids and all my family members for their great understanding. Besides that thank you very much to all Politeknik Hulu Terengganu staffs and students for their cooperation.

\section{References}

Alias, A. B., \& Rashid, N. A. B. N. (2018). The relationship between students' second language learning anxiety and language proficiency. Journal of Counseling and Educational Technology, 1(2), 50. https://doi.org/10.32698/014H. V.

Baharudin, S. S., \& Md. Rashid. S. (2014). English Language Learning Anxiety and Oral Performance Among Undergraduate Esl Learners. Journal of Language and Communication, 1(2), 135-151 (2014). Page 147.

Hashimoto, Y. (2002). Motivation and willingness to communicate as predictors of reported L2 use: The Japanese ESL context. University of Hawai'I Second, 20(2) (2002), p.p 29-70.

Mahfuzah, R., Rafidah, A. K., \& Akma, F. A. (2015). Fear of Negative Evaluation in Second Language Learning.

Miskam, N. N., \& Saidalvi, A. (2018). Investigating English Language Speaking Anxiety among Malaysian Undergraduate Learners. Asian Social Science, 15(1), 1. https://doi.org/10.5539/ass.v15n1p1

Spielberger, C. D. (1983). Manual for the State-Trait Anxiety. Consulting Psychologists Press, Palo Alto, CA. (1983), p.p 4. 